\title{
Immunomodulatory effect of Moringa peregrina leaves, ex vivo and in vivo study
}

\author{
IBRAHIM SALAMEH AL-MAJALII, SAWSAN ATALLAH AL-ORAN², MONA RUSHDIE HASSUNEH', \\ HAITHAM NAIEF AL-QARALLEH ${ }^{3}$,WALID ABU RAYYAN ${ }^{4}$, OSAMA YOSEF AL-THUNIBAT ${ }^{5}$, \\ EYAD MALLAH ${ }^{6}, A H M E D A B U-R A Y Y A N^{7}$, SHADI SALEM $M^{8,9}$
}

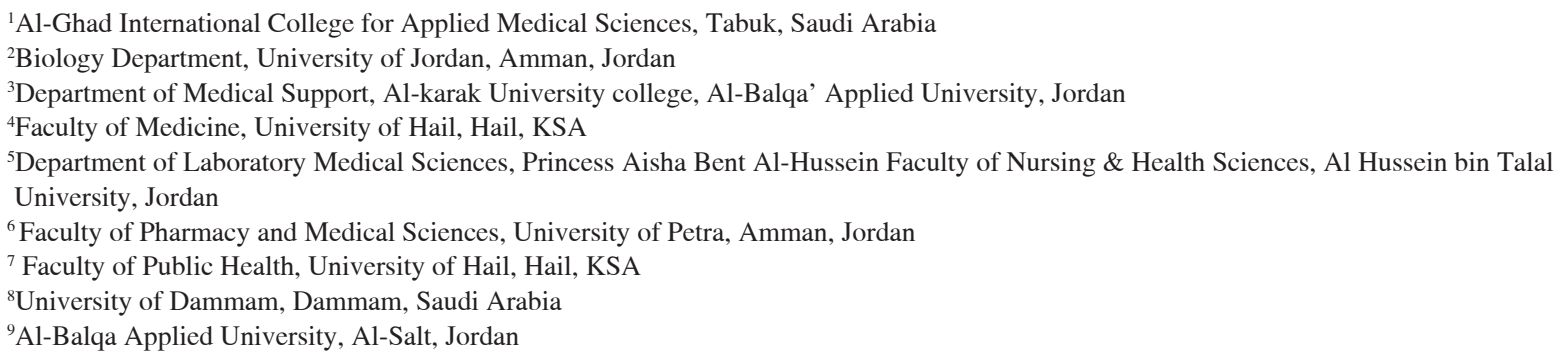

\begin{abstract}
This study was conducted to assess the in vivo and ex vivo immunomodulatory effect of the ethanol leaves extract of Moringa peregrina in Balb/c mice. For this study, five groups of $5 \mathrm{Balb} / \mathrm{c}$ mice were given a single acute subtoxic oral dose of the ethanolic extract at 1.13, 11.30, 23.40 and $113.4 \mathrm{mg} / \mathrm{kg}$ and the immunomodulatory effect was assessed on the $6^{\text {th }}$ day following the ingestion. In the (non-functional) assessment, the effect of the extract on the body weight, relative lymphoid organ weight, splenic cellularity and peripheral blood hematologic parameters were evaluated. While in the immunomodulation assessment (functional), we investigated the effect of the extract on the proliferative capacity of splenic lymphocytes and peripheral $T$ and B lymphocytes using mitogen blastogenesis, mixed allogeneic MLR and IgM-Plaque forming cells assays. The ingestion of M. peregrina extract caused a significant increase in the body weight, weight and number of cells of spleen and lymph nodes of the treated mice. Furthermore, the count of RBCs, WBCs, platelets, hemoglobin concentration and PCV $\%$ were increased by the extract treatment in a dose-dependent manner. $M$. peregrina enhanced the proliferative responses of splenic lymphocytes for both T cell and B-cell mitogens. Likewise, the mixed lymphocyte reaction MLR assay has revealed a T-cell dependent proliferation enhancement in the extract treated mice. Moreover, the oral administration of $M$. peregrina leaves extracts significantly increased PFCs $/ 10^{6}$ splenocytes in a dose-dependent manner. In conclusion, subtoxic acute doses of M. peregrina extract demonstrated significant potential as an immunomodulatory agent even at the lowest dose of $1.13 \mathrm{mg} / \mathrm{kg}$.
\end{abstract}

Key words: Moringa peregrina, immunomodulation, mouse spleen, $T$ and B lymphocytes, body weight.

(Centr Eur Immunol 2017; 42 (3): 231-238)

\section{Introduction}

Herbal implementation in disease therapy is considered a fundamental regiment in folk medicine. Medicinal properties of plants have been described throughout human societies. A small percentage of plants are consumed for nutritional purposes, eventually, most of plants are used for medicinal applications. World widely, there is an exponential reliance on herbal medicine as a remedy for the treatment of several diseases [1]. Recently, the usage of medicinal plants in pharmaceutical industries has attracted big attention, not only because of deleterious toxicity and side effects of newly synthetized drugs but also for the low purchasing capability of the developing societies. In addition, the emergence of new disorders has highlighted on the essential role of medicinal plants as a core for new healing agents in the development of therapeutic drugs [2].

Jordan has a huge variety of wild plants due to its geographical and climatic diversity. In Jordan, there is more than 480 plant species belonging to 99 plant families which have been utilized as medicinal plants [3].

Correspondence: Ibrahim Salameh AL-Majali, Al-Ghad International College for Applied Medical Sciences, Tabuk, Saudi Arabia, e-mail: majali201181@yahoo.com

Submitted: 26.01.2016; Accepted: 26.10.2016 
The genus Moringa which is called miracle tree, belongs to "Moringaceae" family with 14 known species (Moringa oleifera, M. arborea, M. borziana, M. concanensis, M. drouhardii, $M$. hildebrandtii, M. longituba, $M$. ovalifolia, M. peregrine, M. pygmaea, M. rivae, M. ruspoliana and M. stenopetala) [4]. Moringa peregrina is known in Arabic as "Habb El Yasar, Habb El Pan", the seeds are known as "Habba Ghalia". It occurs in nature in dry or semiarid countries neighboring the Red Sea, from Somalia and Yemen to Palestine and to Syria [5].

Medicinal plants play significant roles in the prevention of human life from various pathogenic microorganisms and the diseases. In nature, there are various medicinal plants which are used as immunomodulatory agents [6]. An immunomodulator is a substance which stimulates or regulates the immune system including both innate and adaptive immune responses. The modulation of the immune system by various medicinal plant products has become a subject for scientific investigation [7].

The effect of $M$. oleifera leaves as immunomodulatory were studied in normal and immunosuppressed mice models. Pre-treatment with Moringa extract inhibited cyclophosphamide bone marrow suppressive effect on phagocytic activity in mice [8]. Furthermore, various doses of Moringa oleifera caused a significant increase in the level of white blood cell counts and immunoglobulin levels [9].

Moringa rich in ginseng and ginseng saponins was reported to have antioxidant, anti-inflammatory, anti-apoptotic and immune-stimulant properties, this raised the theory that Moringa plant and its extracts could play a part in immunomodulation [10].

The aim of this study to casts a light on the feasibility of the "Miracle tree" Moringa peregrina as immunomodulatory as medicinal plant in Jordan

\section{Material and methods}

\section{Plant material}

The Moringa peregrina wild leaves were collected on June 2012 from the wade Bin-Hamad in the south of Jordan in karak. Leaves were collected as a semi dried leaf. This plant was been reported by Professor Dawoud Al-Eisawi who is a Professor in plant taxonomy in the University of Jordan.

\section{Preparation of ethanolic extract}

After collection of plant leaves, leaves were dried in the shade at room temperature $\left(27-30^{\circ} \mathrm{C}\right)$ to constant weight. Plant leaves were coarsely powdered using a mortar and pestle and were further reduced to powder using an electric blender. The powder was transferred into closed containers. The shade-dried leaves powder was extracted with $95 \%$ ethanol.

Each $50 \mathrm{~g}$ leave powder was mixed in a conical flask with $500 \mathrm{ml}$ of $95 \%$ ethanol, plugged, then shaken at 120 rpm for 30 minutes and allowed to sediment at room temperature for 72 hours with manual agitation of the flask using a sterile glass rod after every 24 hours. After $72 \mathrm{~h}$, the extract was filtered rapidly through four layers and then by a more delicate filtration through Whitman No 1 filters paper. The resulting filtrate were then concentrated in a rotary evaporator and subsequently left to dryness [11].

\section{Animals}

Inbred female Balb/c mice weighing 20-25 g were purchased from the animal facility at Yarmouk University and housed at the animal facility of University of Jordan. Balb/c males were not used since they become aggressive at around 8 weeks of age and this might affect the immunomodulatory studies [11]. Animals were kept in an air-controlled room and fed with normal mouse chow and water for 7 days.

For allogeneic MLR JVI-1 strain was used from the animal house in the University of Jordan. The study has been approved by the Faculty of Biology at the at University of Jordan and was performed in compliance the Helsinki Declaration following the approval of an independent ethics committee at the Hospital of University of Jordan in Amman, Jordan.

\section{Treatment}

Mice were divided into 5 groups with 5 mice in each group. Each mouse in the four experimental groups received $0.2 \mathrm{ml}$ of a single acute oral gavage of Moringa peregrina ethanolic extract at doses; 1.13, 11.34, 23.40 or $113.4 \mathrm{mg} / \mathrm{kg}$. Mice were sacrificed and all assessments were conducted on the $7^{\text {th }}$ day following ingestion. For the control groups, a single oral gavage was administered to each mouse; received $0.2 \mathrm{ml}$ of distilled water.

\section{Determination of Moringa peregrina leaves median lethal dose $(\mathrm{LD})_{50}$}

Twelve groups, each group consists of $10 \mathrm{Balb} / \mathrm{c}$ mice weighing from 20-25 grams, were used. Each group was treated orally "gavage" with either 750, 1000, 1250 or 1500 $\mathrm{mg} / \mathrm{kg}$ of each leave extract. The dose range was selected based on earlier studies; where oral doses of Moringa peregrina aqueous and ethanolic seed extract ranging between $100-300 \mathrm{mg} / \mathrm{kg}$ were found to be safe yet potent as anti-inflammatory [12]. Also, based on the fact that the i.p. $\mathrm{LD}_{50}$ of fatty acids and unsaponified matter of Moringa peregrina aerial parts was found to be $1134 \mathrm{mg} / \mathrm{kg}$ body weight [13]. The symptoms of toxicity and post-mortality findings were recorded within 24 hours after extract oral gavage administration. The percentage of mortality was calculated (Number of dead mice per group/Total number of each group), and plot the \% mortality against the logarithmic dose of Moringa peregrina extract. A trendline was drawn and the $\mathrm{LD}_{50}$ values were calculated from each equation (Hayes, 2001). 


\section{Body and relative organ weight}

The body weights of animals in each group (control and four treatment groups) were recorded at the beginning and at the end of the experimental treatment. Mice were sacrificed by ether overdose at the $7^{\text {th }}$ day following the acute dose application and organs such as the spleen, thymus, and six selected lymph nodes (a pair of the axial, cervical, and inguinal lymph nodes) were removed, weighed and recorded as the relative organ weight.

After weight recorded, in the laminar flow hood each mouse placed on a filter paper and $70 \%$ ethanol was applied on the mouse fur, a midline incision was made, and the skin was withdrawn above the head and below the thighs by pulling it slowly with gloved fingers. Major lymph nodes (2 axillaries, 2 cervical, and 2 inguinal) were taken and placed in a sterile plastic tissue culture plate then weighed. The abdominal muscles were then cut and the spleen was removed and placed in complete RPMI medium in a sterile plate tissue culture then weighted and placed at $4^{\circ} \mathrm{C}$. The thoracic cavity was then opened and the thymus gland removed and weighted. For all organs, connective and adipose tissues were removed before weighing.

\section{Single cell suspension (SCS) of mononuclear cells}

Mononuclear cells were cultured in complete RPMI 1640 medium (fetal calf serum (Bovine) (FCS) (Gibco), $2 \mathrm{mM}$ L-glutamate (Applichem), $10 \mathrm{mM}$ HEPES buffer (N-2-hydroxethylpiperezin-N-(2-ethanesulfonic acids) (Applichem), $50 \mu \mathrm{M}$ mercaptoethanol (2-ME), and 1\% (W/V) penicillin/streptomycin solution (Gibco)). Under the laminar flow hood, the spleen was teased between the frosted edges of two sterile microscopic slides. The released cells were collected from the plates into a sterile centrifuge tube by adding $10 \mathrm{ml}$ cRPMI-1640-5\% media. The tubes were centrifuged at $1200 \mathrm{rpm}$ for 10 minutes at $4{ }^{\circ} \mathrm{C}$ in sawing bucket refrigerated centrifuge (ALC, PK121R). Supernatants were discarded, and the pellet suspended in $3 \mathrm{ml}$ of RBCs lysing buffer containing $0.83 \%$ $\mathrm{NH} 4 \mathrm{Cl}$ in $100 \mathrm{mM}$ tris buffer, pH 7.4 (Sigma Chemical $\mathrm{Co}$ ) and kept at room temperature for $3 \mathrm{~min}$. The lysed RBCs were washed out of by repeating the above step 3 times. Following the last wash and removing the supernatant, cells were suspended in $2 \mathrm{ml}$ cRPMI-1640-10\% medium and counted using the trypan blue exclusion test [14].

\section{Lymphocyte proliferations (Blastogenesis) in response to mitogen}

This assay is used to measure the proliferative capacity of spleen or peripheral blood $\mathrm{T}$ and $\mathrm{B}$ lymphocytes to polyclonal mitogens such as phytohemagglutinin (PHA), lipopolysaccharide (LPS), and concanavalin A (Con A).

In the current study, the optimal concentration of different mitogen was determined firstly by using different concentrations of mitogens incubated with $0.1 \mathrm{ml}$ of sple- nocytes suspensions from the normal healthy mouse at a density of $8 \times 10^{5}$ per well. The microtiter plates were incubated at $37^{\circ} \mathrm{C}, 95 \%$ humidity, and $5 \% \mathrm{CO}_{2}$-for $48 \mathrm{~h}$. The mitogens used were: LPS as a B cell mitogen, PHA, and Con-A as a $\mathrm{T}$ cell mitogens. The optimal final concentrations were: $4.0 \mu \mathrm{g} / \mathrm{ml}, 20.0 \mu \mathrm{g} / \mathrm{ml}$, and $50 \mu \mathrm{g} / \mathrm{ml}$ for Con-A, LPS, and PHA, respectively. SCS was added in triplicate $0.1 \mathrm{ml} /$ well in cRPMI-10 medium followed by adding an optimal concentration of each mitogen. The microtiter plates were placed in a humidified $37^{\circ} \mathrm{C}, 5 \% \mathrm{CO}_{2}$ incubator [15-17]. After $48 \mathrm{~h} 20 \mu \mathrm{l}$ of MTT (3-(4,5-dimethylthiazol-2-yl)-2,5-diphenyltetrazolium bromide) reagent was added to each well and incubated for 4 hours at $37^{\circ} \mathrm{C}$ and $5 \% \mathrm{CO}_{2}$ incubator. After the end of incubation time, $170 \mu \mathrm{l}$ dimethyl sulfoxide (DMSO) was added. The absorbance of each well was measured at $630 \mathrm{~nm}$ by a microplate reader.

\section{Mixed lymphocytes response (MLR) assay}

The proliferative response of spleen $\mathrm{T}$ lymphocytes to allogeneic cells is measured by the mixed lymphocytes reactions (MLR) as an indicator for cell-mediated immune competence and for detecting chemicals induced immunosuppression or immunostimulation [16]. The responder T lymphocytes present in SCS obtained from the spleen of Moringa peregrina-treated mice were cultured with allogeneic JVI-1 mouse strain. In this MLR, the stimulus is the foreign histocompatibility complex antigen (class 1 or class 2 molecules) expressed on the allogeneic stimulators cells. The proliferation of the stimulators lymphocytes is prevented by treatment with mitomycin C. The MLR was conducted as described by Kruisbeek et al.

\section{IgM plaque-forming cell (PFC) assay}

At the third day of treatment, all mice were immunized by intravenous injection of $0.2 \mathrm{ml}$ of sheep red blood cell SRBCs $5 \%\left(\sim 5 \times 10^{8}\right.$ cells $)$ through the retro-orbital plexus [18]. The intravenous route is chosen to ensure responding lymphocytes to be in the spleen [19]. Then mice were sacrificed on the $7^{\text {th }}$ day, the spleen was taken and prepared SCSs.

The spleen was taken from each mouse and SCS were prepared in cRPMI 1640-10 medium as described above. Guinea-pig complement serum was absorbed with SRBCs prior to eliminating any SRBC reactive components. This was accomplished by adding $100 \mu \mathrm{l}$ packed SRBCs to $1 \mathrm{ml}$ of complement and incubated for $20 \mathrm{~min}$ at $4^{\circ} \mathrm{C}$. Then the mixture was centrifuged for $7 \mathrm{~min}$ at $4^{\circ} \mathrm{C}$ and $1500 \mathrm{rpm}$. The SRBCs absorbed complement was taken into a fresh sterile tube, and the SRBCs were discarded. The complement preparation was diluted to $1: 2$ before use since this was found to be the best dilution to produce clear plaques during the preliminary experiment. The immune reaction was done in $1 \mathrm{ml}$ mixture as follows: $100 \mu \mathrm{l}$ of diluted complement, $300 \mu \mathrm{l}$ of $12 \%$ SRBCs and $600 \mu \mathrm{l}$ of spleen SCS containing $1 \times 10^{6}$ cells. Such mixture was done for each 
mouse in all experimental and control group. Cunningham slide chambers were prepared as described by [15], and 35 $\mu \mathrm{l}$ of each mixture prepared as above were pipetted into each chamber, sealed using petroleum gel to prevent evaporation. Control slides containing SCS from non-immunized mice were included. Slides were incubated at $37^{\circ} \mathrm{C}$ for 1.0 to 1.5 hrs until plaques are fully visible. The number of plaques per chamber was counted and the number of PFCs per million spleen cells was calculated $[11,15,17]$.

\section{Statistical analysis}

Immunomodulatory results expressed as the mean $\pm \mathrm{SE}$ (standard errors). One way analysis of variance (ANOVA) was used for statistical analysis followed by a T-independent test to determine the difference between treated group and control group. $P \leq 0.05$ is considered significant.

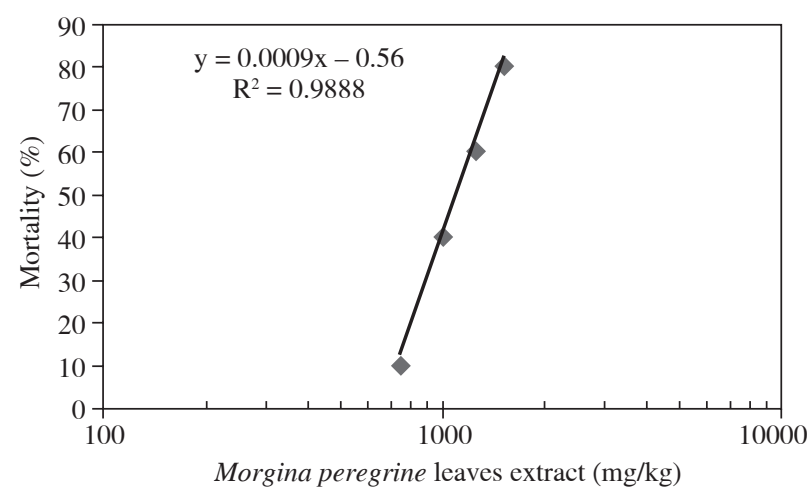

Fig. 1. Mortality of mice treated with Moringa peregrina leaves extract $(\mathrm{mg} / \mathrm{kg})$ following a single oral dose

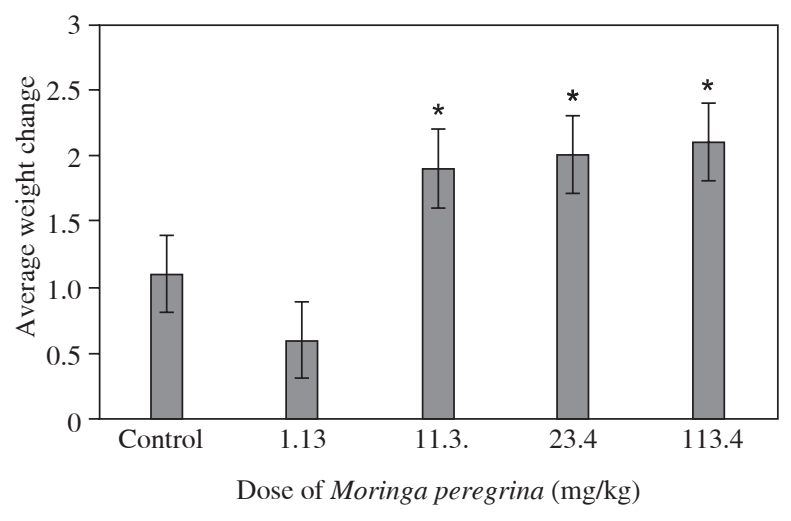

*Significant as compared to the predetermined level of $p \leq 0.05$

Fig. 2. Effect of Moringa peregrina leaves extract on the average body weight of mice. Data represent the mean body weight change $(\mathrm{g}) \pm \mathrm{SE}$

\section{Results}

\section{Moringa peregrina leaves median lethal dose $\left(\mathbf{L D}_{50}\right)$}

The LD50 values of Moringa peregrina leaves extract following oral administration to mice were in Fig. 1.

\section{Relative body weight}

The effect of acute ingestion of Moringa peregrina ethanolic extract on the relative body weight, throughout the treatment period till the time of sacrifice, no visible signs of toxicity or mortality were noted. However, the leaves extract significantly increased the relative body weight of treated mice as in Fig. 2.

\section{Effect of Moringa peregrina extracts on relative weights of lymphoid organs (spleen, thymus and lymph nodes)}

Oral administration of the leaves extracts increased significantly the relative mass of lymphoid organs for each $100 \mathrm{~g}$ of body weight of spleen and lymph nodes in Fig. 3.

\section{Effect of Moringa peregrina extract on spleen cellularity}

The effect of acute administration of Moringa peregri$n a$ leaves ethanolic extract on spleen cellularity of Balb/c mice. Low doses (1.13 and $11.30 \mathrm{mg} / \mathrm{kg}$ ) of leaves extract increased spleen cell number whereas higher doses (23.40 and $113.40 \mathrm{mg} / \mathrm{kg}$ ) decreased spleen cell number in Fig. 4.

\section{Effect of Moringa peregrina extracts on hematological parameters}

The effect of six days oral treatment of Moringa peregrina ethanolic extract on the hematopoiesis of Balb/c mice, increasing concentration of leaves extracts significantly increased RBCs number, hemoglobin, and platelets and PCV \% in Fig. 5.

\section{Effect of Moringa peregrina extract on peripheral blood total white cells WBCs counts}

Acute orally administration of increasing concentrations of Moringa peregrina ethanolic extract for six days to mice statically significant increased total WBCs numbers in peripheral blood in Fig. 6.

\section{Effect of Moringa peregrina extract on mitogen blastogenesis response}

The effect of acute treatment of Moringa peregrina ethanolic extract on the proliferations of T\&B lymphocytes on Balb/c mice. The results showed that the splenocytes from different orally treated groups were proliferated in 


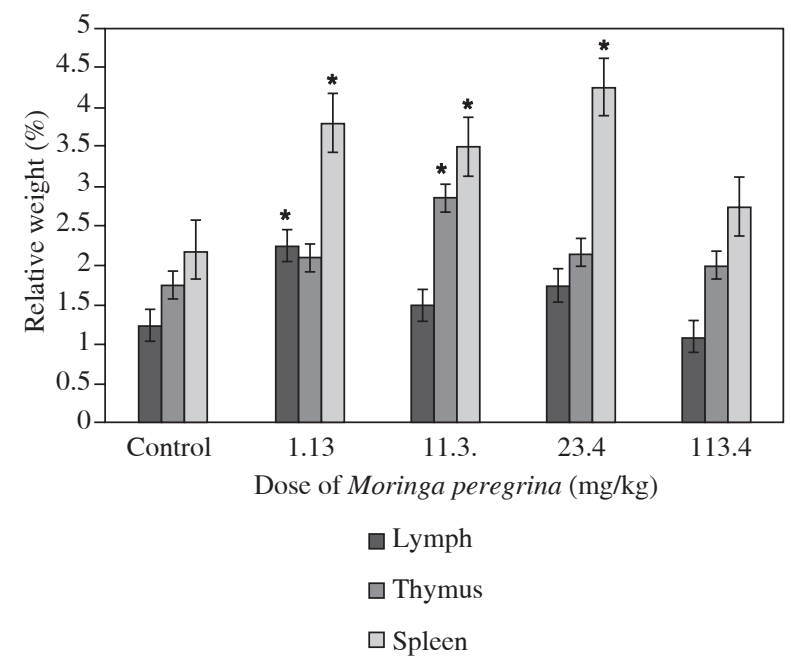

*Significant as compared to the predetermined level of $p \leq 0.05$

Fig. 3. Effect of Moringa peregrina leaves extract on the $\%$ relative lymphoid organs' weights. A) Lymph Nodes relative mass. B) Thymus relative mass. C) Spleen relative mass. Data represent the mean $\pm \mathrm{SE}$

A

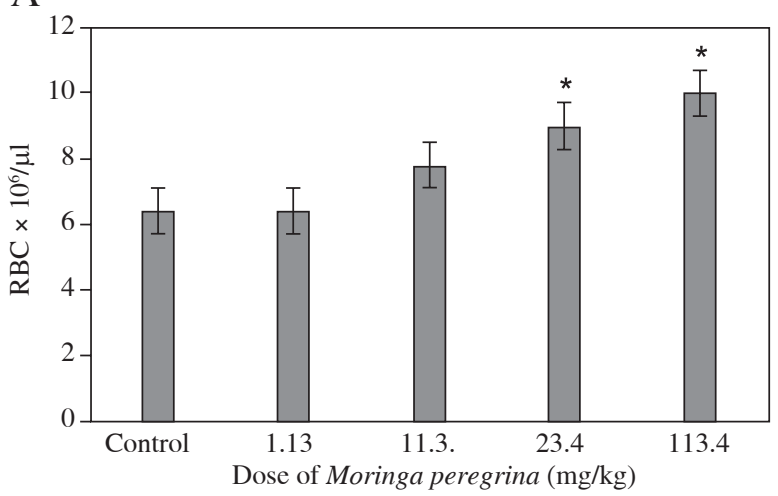

$\mathrm{C}$

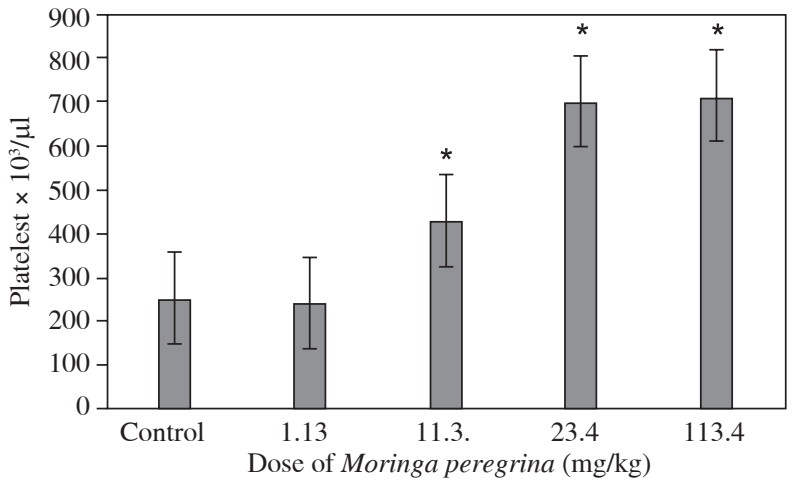

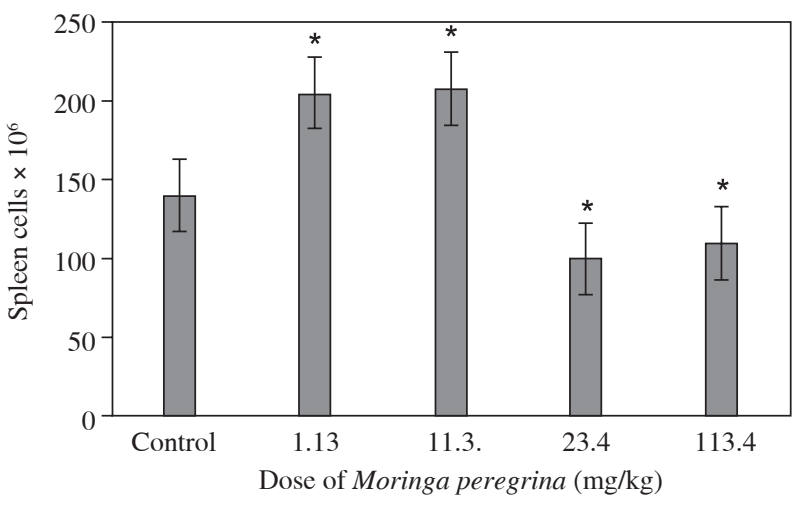

*Significant as compared to the predetermined level of $p \leq 0.05$

Fig. 4. Effect of Moringa peregrina leaves extract on the cellularity of the spleen as compared with the control group. Data represent the mean $\pm \mathrm{SE}$
B

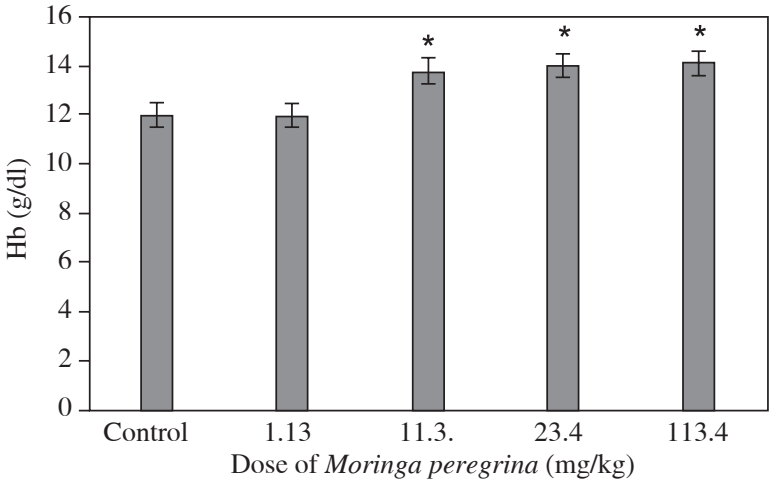

D

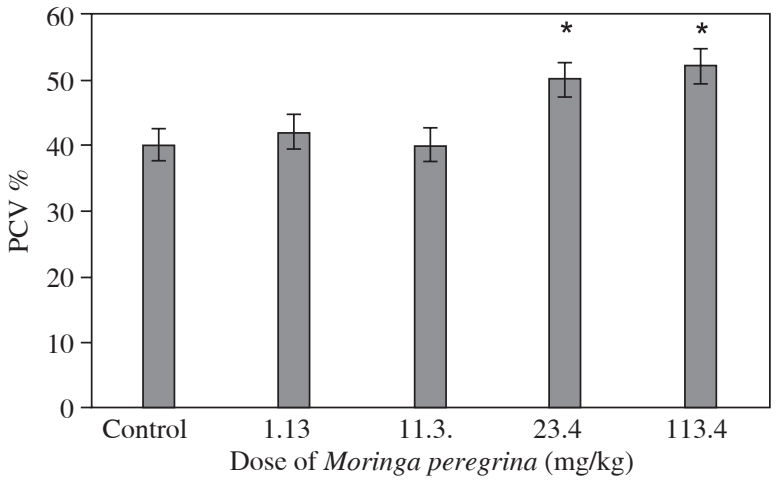

*Significant as compared to the predetermined level of $p \leq 0.05$

Fig. 5. Effect of Moringa peregrina leaves extract on hematological parameters. A) RBC $\times 10^{6}$. B) Hemoglobin (g/dl). C) Platelets $\times 10^{3}$. D) PCV \%. Data represent the mean \pm SE 


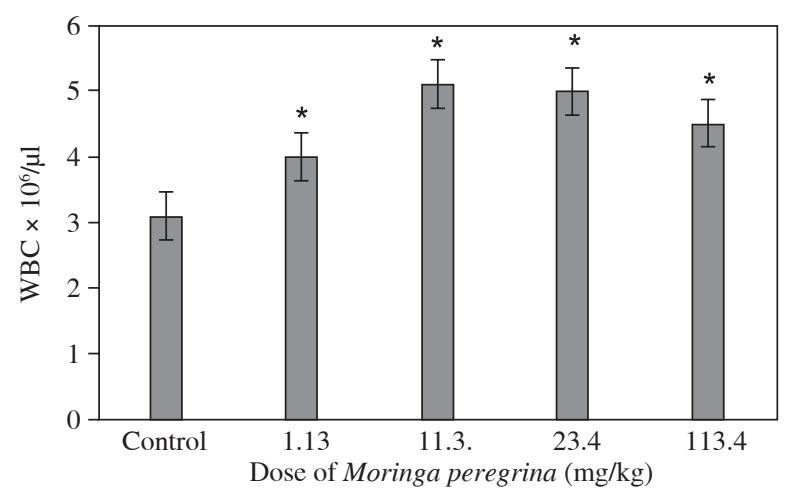

*Significant as compared to the predetermined level of $p \leq 0.05$

Fig. 6. Effect of Moringa peregrina leaves extract on total WBC number. Data represent the mean $\pm \mathrm{SE}$

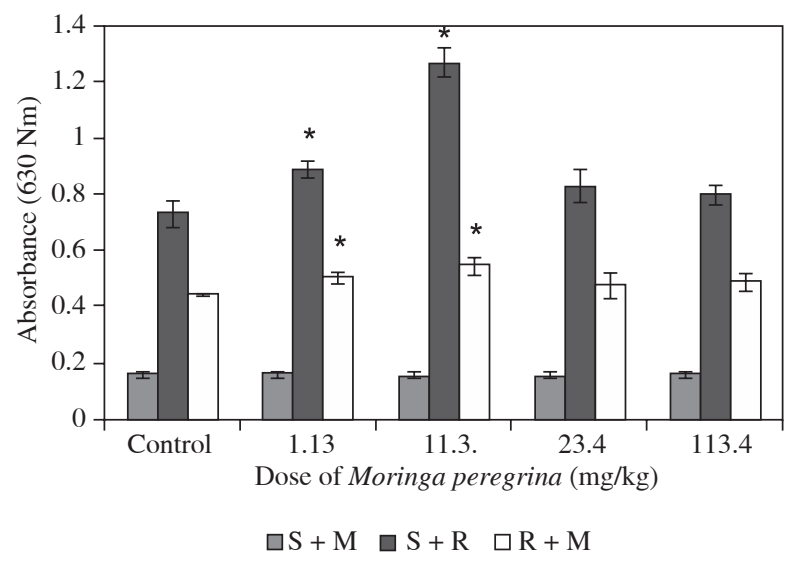

$\mathrm{R}$ - respond mice cells; $\mathrm{S}$ - stimulators rat cells; $\mathrm{M}$ - cRPMI-1640 complex media

* Significant as compared to the predetermined level of $p \leq 0.05$

Fig. 8. Effect of Moringa peregrina leaves extract on the $\mathrm{T}$ lymphocyte proliferation. Data represent the mean $\pm \mathrm{SE}$

the absence of any mitogen. In stimulated lymphocytes cultures, PHA shows the highest degree of response, i.e. lymphocytes proliferation.

In LPS, PHA, or Con-A stimulated lymphocytes, low doses $(1.13$ and $11.30 \mathrm{mg} / \mathrm{kg})$ of leaves extract significantly increased lymphocyte proliferation more than higher doses $(23.40$ and $113.40 \mathrm{mg} / \mathrm{kg}$ ) in Fig. 7.

\section{Effect of Moringa peregrina extraction mixed lymphocyte reaction}

The effect of acute treatment of Moringa peregrina ethanolic extract on the proliferation of $\mathrm{T}$ cells from Bal$\mathrm{b} / \mathrm{c}$ mice, Low doses (1.13 and $11.30 \mathrm{mg} / \mathrm{kg}$ ) of leaves

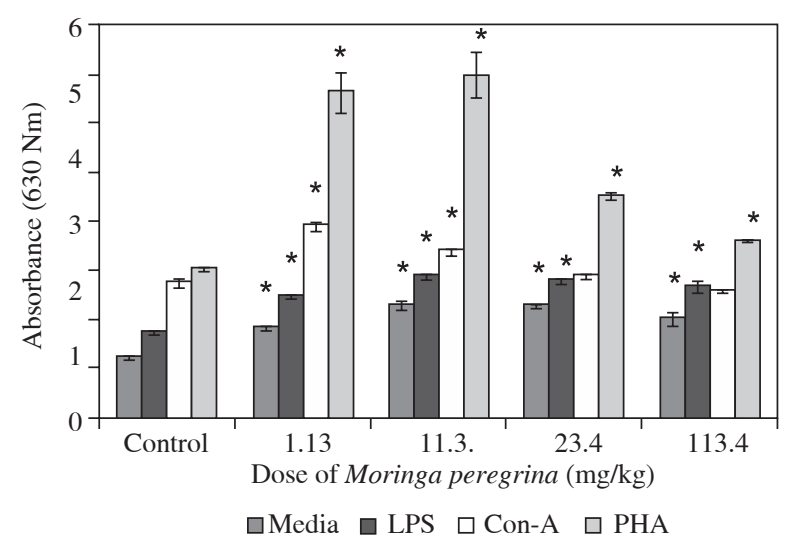

*Significant as compared to the predetermined level of $p \leq 0.05$

Fig. 7. The lymphocyte cell proliferation in the spleen in presence or absence of mitogen Moringa peregrina leaves extract in the absence or the presence of different mitogen (LPS, Con-A, and PHA). Data represent the mean \pm SE

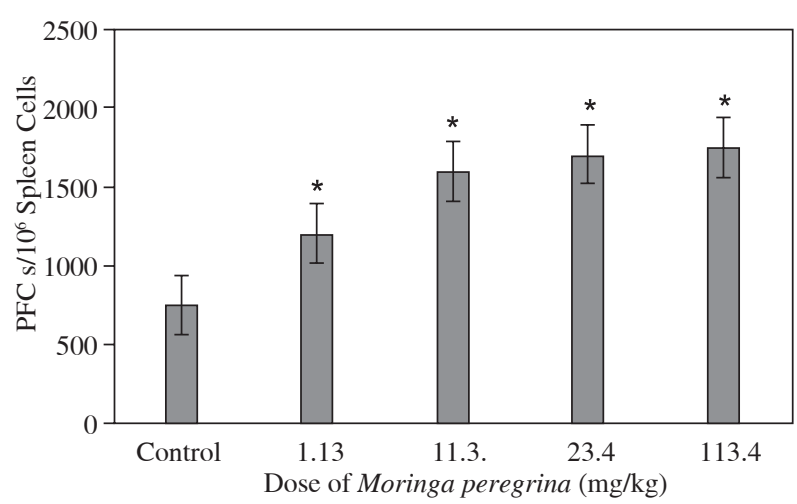

*Significant as compared to the predetermined level of $p \leq 0.05$

Fig. 9. Effect of Moringa peregrina leaves extract on the humoral response as assessed by the IgM-M Plaque-Forming Cell Assay (PFCs). Data represent the mean $\pm \mathrm{SE}$

extract significantly increased $\mathrm{T}$ lymphocyte proliferation in the absence and presence of allogeneic stimulators rat cells but not at higher doses (23.40 and $113.40 \mathrm{mg} / \mathrm{kg}$ ) in Fig. 8.

\section{Effect of Moringa peregrina extract on immunoglobulin-M (IgM) plaque-forming cell (PFC) Assay}

The effect of acute treatment of Moringa peregri$n a$ ethanolic extract on the humoral response, oral administration of leaves extract for 6 days significantly increased PFCs $/ 10^{6}$ splenocytes in a dose-dependent manner in Fig. 9. 


\section{Discussion}

Medicinal plants have been widely used in traditional (folk medicine) health care systems throughout human history and are still one of the most important health care sources in many regions of the world [20]. There is an increasing interest in medicinal plants and homeopathic contemporary medicine especially with the raised awareness of toxic or unwanted side effects of classical drugs [21]. The current study aimed to assess the immunomodulatory effects of the endemic Jordanian Moringa peregrina plant. There are a plethora of studies assessing the role of the Moringa plant in folk medicine in many countries as in these example references $[8,13]$. However, there are neither actual uses of Moringa peregrina in Jordan, nor studies done to assess its immunomodulatory activity of the Jordanian Moringa peregrina ethanolic extract. Therefore, the present study examined the effect of the short-term application of the ethanolic extracts of Moringa peregrine leaves on the immune system and hematopoiesis.

The treatment with different doses of the Moringa peregrina ethanolic extract was well tolerated by all the animals, as there were no toxic effects observed by direct visual observation of the animals throughout the experiment. There was no death and apparent behavioral changes recorded during the course of the experiment in all treatment groups as compared to the control group. Moreover, the administration of Moringa peregrina leaves ethanolic extract stimulated the increase in the size of body weight of treated mice. This increase in the mice weight may be due to the fact that Moringa is a good source of nutrition. This is consistent with the previous studies reported that Moringa contains important nutrients such as vitamins, proteins, minerals, carbohydrates and fats [22]. Research on the nutritional potency of Moringa showed that Moringa is an ideal energy of food, Moringa peregrina leaves are a good source of vitamins, minerals, proteins and very low fats and carbohydrates. Leaves and pods have several amino acids (methionine and cysteine) [23]. Moringa peregrina dry leaves are good sources of protein (17-amino acids found in leaves and seeds, 9 were classified as essential amino acids) and essential minerals comparable to those recorded for Moringa oleifera [24]. The leaves can actually be eaten raw, but best added in meals as a special ingredient, or diet supplement that can help offset a typically unhealthy Western diet due to its high concentration of nutrients [25]. Additionally, oral administration of leaves extract has increased the relative weight of spleen and lymph nodes. The weight increase of spleen and six lymph nodes resulted from an increase of the number of proliferations of lymphocytes cells inside lymphoid organs. As for the thymus gland, which is the primary site for T lymphocytes maturation. A similar finding was reported with Moringa oleifera leaves ethanolic extract in normal and immunosuppressed mice [8].
Oral administration of Moringa peregrina leaves ethanolic extract at low doses increased spleen cell number whereas higher doses decreased it, this may be result of migrations of lymphocytes from spleen to the circulation at the high concentrations or due to the presence of toxicant such as isothiocyanate and glycoside cyanide and zinc and iron that may pose stress at high concentration and hence reducing the spleen cell number [24].

Hematopoiesis is the process by which hematopoietic stem cells and immature precursor cells develop into mature blood cells. Measuring hematological parameters following 6 days of oral administration of Moringa peregrina leaves ethanolic extracts increased the RBCs number, hemoglobin, platelets and PCV \%. Moringa peregrina extract effect the hematopoiesis process in the bone marrow.

Oral gavage of increasing concentrations of Moringa peregrina leaves ethanolic extracts for six days to mice significantly increased total WBCs numbers in the peripheral blood. Similar results were obtained with Moringa oleifera leaves ethanolic extract [8,9]. Such leucopoiesis effect could enhance immune response towards infectious agents. In order to explore the previous finding, mitogen blastogenesis assay was performed in response to three different mitogens. These mitogens are known to trigger signal transduction pathways in which mitogen-activated protein kinase (MAPK) were involved, leading to mitosis [26]. This assay was done to test the immunostimulator/immunomodulator of B and/or T lymphocytes taken from the spleen of Balb/c mice. The results showed that the splenocytes from mice treated orally for six days with Moringa peregrina extract proliferated in the absence of any mitogen, which means that Moringa peregrina ethanolic extract can induce lymphocytes proliferations. Similarly, ex vivo splenic lymphocytes from different orally treated groups proliferated in the absence of any mitogen. In PHA-stimulated spleen cells, however, the maximum stimulation was observed at low doses of leaves extract. Similar results from mixed lymphocyte reaction MLR assay were observed. Oral administration of leaves extract for six days significantly increased PFCs $/ 10^{6}$ splenocytes in a dose-dependent manner. These findings indicated that certain constituents of Moringa peregrina leave ethanolic extract possess potent compounds effects on the cellular and humoral immunity.

MLR indicated that the oral treatment of Moringa peregrina ethanolic extracts for six days on Balb/c mice enhanced the cellular immunity response. After 6 days of treatment the mice expressed a significant increase in proliferation process when mixed with the rat allogeneic splenocytes cells. Low doses of leaves extract increased $\mathrm{T}$ lymphocyte proliferation in the absence and presence of allogeneic stimulators rat cells but not at higher doses. These findings indicated that certain constituents of Moringa peregrina leave ethanolic extracts posses potent compounds effects on T cell-mediated immunity. The PFC 
assay is a measure of plasma cells that can be generated when B lymphocytes are properly activated by antigen. The PFC assay is an extremely sensitive and antigen-specific assay since generations of antibody forming cells forms a few hundred native B lymphocytes in a mixture of a million or more lymphocytes can be detected with high accuracy and specificity [27]. The results of the current study indicate that oral administration of Moringa peregrina ethanolic leaves extract for six days significantly increased PFCs $/ 10^{6}$ splenocytes in a dose-dependent manner. Thus, the results showed that the oral treatment of Moringa peregrina ethanolic extracts for six days on $\mathrm{Balb} / \mathrm{c}$ mice enhanced the humoral immunity as well. This is parallel with the results [28] demonstrating that Moringa oleifera extract at doses of 250 and $750 \mathrm{mg} / \mathrm{kg}$ increased total serum IgM levels. The extract was found to be most effective at a low dose $(250 \mathrm{mg} / \mathrm{kg})$, whereas, high dose $(750 \mathrm{mg} /$ $\mathrm{kg}$ ) of methanolic extract of Moringa oleifera was moderately effective in modulating immune system [28].

\section{The authors declare no conflict of interest.}

\section{References}

1. Taylor R, Manandhar N, Towers G (1995): Screening of selected medicinal plants of Nepal for antimicrobial activities. J Ethnopharmacol 46: 153-159.

2. Verma S, Singh S (2008): Current and future status of herbal medicines. Veterinary World 1: 347-350.

3. Oran S, Al-Eisawi D (1998): Check-list of medicinal plants in Jordan. Dirasat. Medical and Biological Sciences 25: 84-112.

4. Olson ME (2002): Combining data from DNA sequences and morphology for a phylogeny of Moringaceae (Brassicales). Systematic Botany 27: 55-73.

5. Somali M, Bajneid M, Al-Fhaimani S (1984): Chemical composition and characteristics ofMoringa peregrina seeds and seeds oil. Journal of the American Oil Chemists' Society 61: 85-86.

6. Sainis K, Sumariwalla P, Goel A, et al. (1997): Immunomodulatory properties of stem extracts of Tinospora cordifolia: cell targets and active principles. In Immunomodulation. Upadhyay SN (ed.). Narosa Publication House, New Delhi, India, pp. 95.

7. Sherwood ER, Toliver-Kinsky T (2004): Mechanisms of the inflammatory response. Best Pract Res Clin Anaesthesiol 18: 385-405.

8. Gupta A, Gautam MK, Singh RK, et al. (2010): Immunomodulatory effect of Moringa oleifera Lam. extract on cyclophosphamide induced toxicity in mice. Indian J Exp Biol 48: 1157-1160.

9. Adedapo AA, Abatan MO, Idowu SO, et al. (2005): Toxic effects of chromatographic fractions of Phyllanthus amarus on the serum biochemistry of rats. Phytother Res 19: 812-815.

10. Rausch W-D, Liu S, Gille G, et al. (2006): Neuroprotective effects of ginsenosides. Acta Neurobiol Exp (Wars) 66: 369375 .

11. Todehdehghan F, Motedayen MH, Tajik P, et al. (2009): Study of zoonotic bacteria in conventional laboratory mice breeding colonies. Iranian Journal of Veterinary Medicine 3.
12. Molska GR, Negri G, Paula-Freire LI, et al. (2014): Phyllanthus amarus does not affect hypernociception in experimental autoimmune encephalomyelitis. Planta Med 80: 277-282.

13. Elbatran SA, Abdel-Salam OM, Abdelshfeek KA, et al. (2005): Phytochemical and pharmacological investigations on Moringa peregrina (Forssk) Fiori. Natural Product Sciences.

14. Strober W (2001): Trypan blue exclusion test of cell viability. Curr Protoc Immunol A. 3B. 1-A. 3B. 2.

15. Kruisbeek AM, Shevach E, Thornton AM (2004): Proliferative assays for $\mathrm{T}$ cell function. Curr Protoc Immunol Chapter 3 Unit 3.12.

16. Hudson L, Hay FC, Hudson L, Practical immunology, Blackwell Scientific Oxford: 1976.

17. Bin-Hafeez B, Haque R, Parvez S, et al. (2003): Immunomodulatory effects of fenugreek (Trigonella foenum graecum L.) extract in mice. Int Immunopharmacol 3: 257-265.

18. Rai V, Mehrotra S (2008): Chromium-induced changes in ultramorphology and secondary metabolites of Phyllanthus amarus Schum \& Thonn - an hepatoprotective plant. Environ Monit Assess 147: 307-315.

19. Coico R, Sunshine G, Benjamini E (2003): Antibody structure and function. Immunology, $5^{\text {th }}$ ed. John Wiley \& Sons, Hoboken 39-57.

20. Heinrich M (2000): Ethnobotany and its role in drug development. Phytotherapy Res 14: 479-488.

21. Uprety Y, Asselin H, Dhakal A, et al. (2012): Traditional use of medicinal plants in the boreal forest of Canada: review and perspectives. J Ethnobiol Ethnomed 8: 7.

22. Fuglie L (1999): The miracle tree: Moringa oleifera. Dakar, Senegal: Church World Services.

23. Makkar H, Becker K (1997): Nutrients and antiquality factors in different morphological parts of the Moringa oleifera tree. J Agricultural Sci 128: 311-322.

24. Osman HE, Abohassan AA (2012): Morphological and analytical characterization of Moringa peregrina populations in western Saudi Arabia. Int J Theor Appl Sci, 4: 174-184.

25. Yang R-Y, Chang L-C, Hsu JC, et al. (2006): Nutritional and functional properties of Moringa leaves - from germplasm, to plant, to food, to health. Moringa leaves: Strategies, standards and markets for a better impact on nutrition in Africa. Moringanews, CDE, CTA, GFU. Paris.

26. Davis S, Vanhoutte P, Pages C, et al. (2000): The MAPK/ ERK cascade targets both Elk-1 and cAMP response element-binding protein to control long-term potentiation-dependent gene expression in the dentate gyrus in vivo. J Neurosci 20: 4563-4572.

27. Bondada S, Robertson DA (2003): Assays for B lymphocyte function. Curr Protoc Immunol 3.8. 1-3.8. 24.

28. Sudha P, Asdaq SMB, Dhamingi SS, et al. (2010): Immunomodulatory activity of methanolic leaf extract of Moringa oleifera in animals. Indian J Physiol Pharmacol 2010; 54:133140 . 